日心第73回大会 (2009)

第1日 9月26日（木） 15:00〜 17:00 清心館507

\title{
WS030＼cjkstart児童生徒のソーシャルスキルと学校適応 〜アセスメントと介入の実証研究
}

\begin{tabular}{|c|c|c|}
\hline 企 画 者 & 関西学院大学 & 松見 淳子 \\
\hline 企 画 者 & 関西学院大学 & 大対香奈子 \\
\hline 司 会 者 & 関西学院大学 & 大対香奈子 \\
\hline 会 者 & 関西学院大学 & 松見 淳子 \\
\hline 提供者 & 日本学術振興会（関西学院大学） & 野田 \\
\hline 提供者 & 大阪府立子どもライフサポートセンター & 福井 \\
\hline 保 & 宮崎大学 & 石川 \\
\hline 提供三 & 高知大学 & \\
\hline
\end{tabular}

\section{概 要}

児童生徒の引きこもりや不登校・抑うつなどの臨床問題、学習困難や発達障害などの発達問題は、学校適 応に深刻な影響を与える問題であり、効果的な支援法の開発が求められている。学校適応に影響する要因の 中でも、特に対人（友人）関係に関する要因は最も強い影響力があることが報告されており、児童生徒の仲 間づきあいについてのアセスメント研究や、学級・グループ単位で指導するソーシャルスキルトレーニング （SST）等の介入プログラム開発の研究は増えている。本ワークショップでは、児童・生徒の学校適応促進を 目指した、教育現場や教育関連施設での実践報告を行い、現在までの成果と今後の課題について検討する。 話題提供者には、不登校・ひきこもりの青年が入所する施設で実施している SST、青年期の抑うつに焦点を あてた学校現場での介入、予防的介入として学校規模で行った SST について、それぞれ実証研究に基づき成 果を発表していただく。 